\title{
Analisis post mortem kulit kambing mentah yang diolah di UPTD penyamakan kulit Padang Panjang
}

\section{Post mortem analysis of raw goatskins processed in UPTD of leather tannery Padang Panjang}

\author{
Sri Mutiar ${ }^{1}$, Anwar Kasim ${ }^{2 *}$, Emriadi ${ }^{3}$, Alfi Asben ${ }^{2}$ \\ ${ }^{1}$ Program Studi Ilmu Pertanian, Fakultas Pertanian Universitas Andalas, Padang, Indonesia \\ ${ }^{2}$ Fakultas Teknologi Pertanian, Universitas Andalas, Padang, Indonesia \\ ${ }^{3}$ Fakultas Matematika dan Ilmu Pengetahuan Alam, Universitas Andalas Padang, Indonesia \\ *Penulis korespondensi. Kampus Limau Manis Padang 25163 Tel.: +62751 72701, 72702; Faks.: +62 75172702 \\ Email : anwarkss@yahoo.com
}

Diterima: 15 Desember 2020

Direvisi: 6 April 2021

Disetujui: 20 April 2021

\begin{abstract}
The purpose of this study was to determine the percentage of rawhide that met the requirements for tanning and rejection and to determine the quality level of rawhide from several areas that used UPTD services for tanning process. The sample was taken by purposive random sampling of 100 pieces of rawhide goat skin before the tanning process was carried out at the UPTD leather processing. Data processing used descriptive statistical analysis using Microsoft Excel. The results of expert observations at the UPTD processing rawhide that met the requirements for the tanning process were $93.22 \%$ and the average rejects skin hide was $6.45 \% \pm 1.33$. The quality of raw leather from several areas that use UPTD services for leather tanning is mostly of quality 2 and quality 3. Based on the observation of the average dimensions of rawhide preserved salt has an area of $4.78 \mathrm{ft}^{2}$, length of $88.81 \mathrm{~cm}$, the width of $64.31 \mathrm{~cm}$, and a thickness of $1.49 \mathrm{~mm}$. Based on the defects in the rawhide, the highest score was due to tick bumps as much as $14 \%$.
\end{abstract}

Keywords: goat skin, postmortem, quality, reject skin.

\section{ABSTRAK}

Tujuan dari studi ini untuk mengetahui persentase kulit mentah yang memenuhi syarat untuk disamak dan kulit mentah reject serta untuk mengetahui tingkat kualitas kulit mentah dari sumber baik dari dalam atau dari luar kota yang menggunakan jasa UPTD penyamakan kulit. Pengambilan sampel dilakukan secara purposive random sampling terhadap 100 lembar kulit kambing mentah tanpa memperhatikan memenuhi syarat atau tidak sebelum proses penyamakan. Pengolahan data menggunakan analisis statistik deskriptif dengan menggunakan Microsoft Excel. Hasil pengamatan panelis di UPTD pengolahan kulit mentah yang memenuhi syarat untuk disamak adalah $93,22 \pm 4,15 \%$ dan rata-rata kulit reject adalah $6,45 \pm 1,33 \%$. Kualitas kulit mentah dari beberapa daerah yang menggunakan jasa UPTD untuk penyamakan kulit sebagian besar adalah kualitas 2 dan kualitas 3 . Berdasarkan pengamatan dimensi rata-rata kulit mentah awet garam memiliki luas 4,78 $\mathrm{ft}^{2}$, panjang $88,81 \mathrm{~cm}$, lebar $64,31 \mathrm{~cm}$ dan ketebalan 1,49 mm. Berdasarkan cacat pada kulit mentah nilai tertinggi disebabkan karena benjolan caplak yaitu $14 \%$.

Kata kunci: Kualitas, kulit kambing, kulit reject, post mortem.

\section{PENDAHULUAN}

Kualitas kulit mentah untuk bahan baku penyamakan dapat mengalami penurunan, baik pada saat ternak masih hidup maupun setelah kulit dilepas dari tubuh ternak setelah pemotongan.
Pemeriksaan post mortem merupakan pengamatan yang dilakukan setelah hewan disembelih. Pemeriksaan post mortem pada kulit dilakukan untuk mendeteksi bagian yang abnormal karena adanya suatu cacat (Yudi, 2009; Triatmojo, 2012). Se- 
lain itu kualitas kulit juga dinyatakan dari ukuran kulit tersebut. Salah satu jenis kulit mentah yang digunakan untuk bahan penyamakan adalah kulit kambing. Kualitas ini dipengaruhi oleh perlakuan pada saat sebelum penyamakan, saat penyamakan dan pada saat pengujian (Sutyasmi, 2015) Faktorfaktor yang mempengaruhi kualitas pada kulit kambing diantaranya adalah cacat kulit seperti bulu rontok, benjolan caplak dan tukak serta jumlah lubang pada kulit akibat teriris.

Penentuan kualitas kulit juga dilakukan berdasarkan kandungan kimia dari kulit mentah yang akan digunakan sebagai bahan baku penyamakan kulit. Menurut Mustakim et al. (2010), kualitas kulit mentah juga berkaitan dengan kandungan kimianya diantaranya komposisi serat kolagen, kepadatan protein kolagen, besarnya sudut jalinan berkas kolagen dan tebalnya korium dalam kulit untuk menghasilkan kulit tersamak yang diinginkan. Hakim (2018) juga menyatakan bahwa kualitas kulit ditentukan juga oleh jenis kelamin dan umur hewan, pengaruh umur dan jenis kelamin kambing terhadap kuantitas dan kualitas kulit lebih penting dari pada jenis kambing. Kambing jantan menghasilkan kulit yang lebih berat dibandingkan dengan kambing betina. Begitu pula untuk luas area skin maupun kulit jadinya, kulit kambing jantan lebih besar dari pada kulit dari kambing betina.

Kulit kambing merupakan hasil ikutan pemotongan yang cukup besar proporsinya mencapai $8-12 \%$ dari total berat (Budisatria, 2009). Hal ini merupakan nilai yang paling tinggi diantara hasil ikutan lainnya dan merupakan bahan mentah untuk memproduksi kulit tersamak (Triatmojo, 2012). Jenis kambing yang banyak dikembangkan adalah dari jenis peranakan Etawa yang memiliki banyak keunggulan dibandingkan dengan kambing kampung (kambing Kacang). Kasim et al. (2013) menyatakan bahwa kulit dari jenis kambing Etawa memiliki ukuran yang lebih luas sehingga sangat cocok dijadikan sebagai bahan baku penyamakan kulit.

Di Sumatera Barat terdapat satu-satunya Unit Pelaksana Teknis Daerah (UPTD) penyamakan kulit. UPTD Penyamakan Kulit Padang Panjang merupakan salah satu unit penyamakan kulit di Sumatera Barat yang letaknya berdekatan dengan Rumah Potong Hewan (RPH). Namun demikian, kulit yang diperoleh tidak hanya dari RPH tersebut. Kulit mentah berasal pengumpul, pemotongan ternak pada hari raya Qurban, dan pengusaha kulit. UPTD menyediakan jasa penyamakan kulit bagi pengusaha kulit jadi (leather) dari berbagai daerah seperti Bukittinggi, Padang Panjang, Padang, Solok, Pariaman, Sumatera Utara, Pekanbaru, dan Jambi. Setelah kulit mentah selesai diproses menjadi kulit jadi di UPTD maka pengusaha kulit akan mengambil kulit jadi tersebut.

Pengelompokan kualitas termasuk pemisahan kulit reject dilakukan oleh panelis, yang di UPTD disebut dengan pakar. Panelis tersebut telah berpengalaman selama 20 tahun dan juga ikut bertugas melakukan pengawasan terhadap rangkaian proses penyamakan kulit mentah. Penetapan kualitas kulit mentah oleh panelis dengan memperhatikan parameter-parameter tertentu sebagai pedoman, diantaranya panjang garis punggung, luas kulit, ketebalan kulit, dan cacat pada kulit, sehingga diperoleh beberapa kualitas kulit yang memenuhi syarat untuk disamak dan reject. Penentuan kualitas kulit menurut panelis sudah digunakan sejak awal proses penyamakan kulit dilakukan di UPTD. Selanjutnya kulit yang memenuhi syarat untuk disamak akan dilanjutkan pada proses penyamakan sampai diperoleh kulit tersamak (leather).

Tujuan dari studi ini untuk mengetahui persentase kulit mentah yang memenuhi syarat untuk disamak dan kulit mentah reject serta untuk mengetahui tingkat kualitas kulit mentah dari beberapa daerah yang menggunakan jasa UPTD untuk penyamakan kulit. Hal ini dapat menjadi pedoman bagi pengguna jasa di UPTD, terkait dengan data kulit yang memenuhi syarat dan kulit reject untuk pengambilan keputusan selanjutnya.

\section{BAHAN DAN METODE \\ Bahan Penelitian}

Penelitian ini menggunakan kulit kambing mentah yang diperoleh dari UPTD Pengolahan Kulit Padang Panjang. UPTD ini beralamat di Jalan RPH Silaing Bawah, Kecamatan Padang Panjang Barat, Kota Padang Panjang, Provinsi Sumatera Barat.

\section{Peralatan Penelitian}

Peralatan yang digunakan dalam penelitian ini adalah timbangan, thickness caliper Tipe $0-10 \times 20$ $\mathrm{mm}$, meteran pita.

\section{Metode Penelitian}

Teknik pengambilan sampel secara purposive sampling (Sugiyono, 2011). Data yang telah diperoleh dengan observasi dan wawancara secara 
mendalam, kemudian disajikan dengan bentuk deskripsi terhadap 100 lembar kulit kambing mentah. Parameter yang diamati terhadap kulit mentah adalah dimensi dan cacat pada kulit mentah. Dimensi yang diamati adalah panjang garis punggung, luas kulit kambing, dan ketebalan. Cacat pada kulit mentah yang diamati meliputi bulu rontok, benjolan akibat kutu caplak, terdapat tukak, dan jumlah lubang pada kulit. Penetapan kualitas kulit mentah mengacu kepada Suardana et al., (2008) dimana kualitas kulit kambing mentah ditentukan berdasarkan panjang tengah-tengah dari ekor hingga leher. Pengelompokan kualitas kulit terdiri dari kualitas 1 (panjang kulit $100 \mathrm{~cm}$ dan lebar $70 \mathrm{~cm}$ ), kualitas 2 (panjang kulit $100 \mathrm{~cm}$ dan lebar $60 \mathrm{~cm}$ ), kualitas 3 (panjang kulit $90 \mathrm{~cm}$ dan lebar $55 \mathrm{~cm}$ ), kualitas 4 (panjang kulit $80 \mathrm{~cm}$ dan lebar $50 \mathrm{~cm}$ ), kualitas 5 (panjang kulit $70 \mathrm{~cm}$ dan lebar $45 \mathrm{~cm}$ ), dan kulit reject (panjang kulit kurang dari $70 \mathrm{~cm}$ ). Pengolahan data menggunakan analisis statistik deskriptif dengan bantuan perangkat lunak Microsoft Excel.

\section{HASIL DAN PEMBAHASAN Kulit Kambing}

Kulit yang digunakan dalam penelitian ini adalah kulit kambing Etawa. Kambing peranakan Etawa merupakan kambing hasil persilangan antara kambing Kacang dengan kambing Etawa. Kambing ini merupakan bangsa kambing yang sudah beradaptasi dengan kondisi Indonesia, sehingga sering disebut kambing lokal. Tandatanda tubuhnya berada diantara kambing Kacang dan kambing Etawa (Atabany et al., 2011). Kulit kambing berasal dari restoran, rumah potong hewan dan kulit ternak pada hari raya Qurban serta di Sumatera Barat juga terdapat beberapa rumah makan khas masakan kambing dengan rata-rata pemotongan 2-5 ekor/hari. Untuk menjaga kondisi kulit tidak membusuk, kulit kambing diawetkan dengan pemberian garam dan disimpan dengan metode ditumpuk. Kulit mentah yang masuk ke UPTD pengolahan kulit berasal dari berbagai daerah dengan jenis, ukuran, dan kisaran umur yang beragam.

\section{Hasil Sortasi Kulit Mentah}

Tahap awal dilakukan sortasi terhadap kulit mentah yang masuk dari berbagai daerah. Data hasil sortasi berdasarkan daerah asal disajikan pada Tabel 1. Dari Tabel 1 dapat dilihat daerahdaerah yang menggunakan UPTD untuk mengo- lah kulit mentah. Hasil sortasi kulit yang dilakukan oleh panelis di UPTD adalah kulit mentah, yang memenuhi persyaratan untuk selanjutnya diolah menjadi kulit tersamak, dan kulit reject. Dari data tersebut 93,22\% kulit mentah memenuhi persyaratan kualitas kulit untuk disamak. Jumlah kulit mentah dari kota Padang Panjang merupakan pengguna terbesar jasa pengolahan kulit di UPTD, selanjutnya diikuti beberapa kota lainnya seperti Bukittinggi, Padang, Solok, dan Pariaman. Disamping itu juga terdapat pengusaha kulit dari provinsi lain meskipun persentasinya lebih kecil. Data kulit reject sangat penting bagi pengusaha kulit pemanfaat jasa UPTD dalam upaya memperkecil persentase kulit mentah reject sebelum dibawa ke UPTD.

Kulit mentah yang berasal dari Pariaman merupakan jumlah kulit reject yang cukup tinggi dibandingkan dengan daerah lain. Rata-rata kulit reject dari hasil pengamatan pakar di UPTD pengolahan kulit adalah $6,45 \pm 1,33 \%$. Panelis menyatakan kulit reject sebagian besar dikarenakan proses pemotogan kulit yang tidak benar. Kulit reject disebabkan kulit terpotong, goresan pada kulit akibat sayatan pisau, adanya bagian kulit yang busuk akibat pemberian garam yang tidak merata, dan cacat pada kulit akibat adanya bulu rontok, benjolan caplak, serta tukak. Hal ini sejalan dengan laporan Asosiasi Penyamak Kulit Indonesia (2016) dimana salah satu penyebab kualitas kulit mentah rendah adalah pelaku pemotongan ternak tidak memberikan perlakuan khusus pada kulit mentah pasca pemotongan seperti pengawetan dengan penggaraman untuk menghambat kerusakan. Hal ini mengakibatkan terdapat cacat yang dapat menurunkan kualitas kulit pada saat di sortasi.

\section{Dimensi Kulit Kambing}

Dimensi kulit kambing diperoleh dengan cara pengukuran terhadap panjang kulit, luas, lebar, dan ketebalan kulit kambing mentah. Data hasil pengukuran kulit kambing awet garam menurut kelompok ukuran panjang garis punggung luas kulit disajikan pada Tabel 2. Berdasarkan hasil penelitian berat rata-rata kulit kambing awet garam tiap lembar adalah $1,51 \mathrm{~kg}$. Luas rata-rata kulit kambing awet garam tiap lembar adalah 4,78 $\mathrm{ft}^{2}$. Dimana nilai konversi kulit kambing awet garam dapat diestimasi dari nilai rata-dari tersebut diatas adalah 1 lembar kulit awet garam dibandingkan luas kulit awet garam adalah 1:4,78. Nilai 
Tabel 1. Data hasil sortasi kulit mentah dari berbagai daerah asal di UPTD Penyamakan kulit Padang Panjang.

\begin{tabular}{|c|c|c|c|c|c|}
\hline \multirow[b]{3}{*}{ Kota asal } & \multicolumn{2}{|c|}{ Jumlah kulit } & \multicolumn{2}{|c|}{ Hasil sortasi (kg) } & \multirow[b]{3}{*}{$\begin{array}{c}\text { Persentase reject } \\
(\%)\end{array}$} \\
\hline & & & Jumlah & Jumlah & \\
\hline & Berat (kg) & $\begin{array}{c}\text { Persentase } \\
\quad(\%)\end{array}$ & $\begin{array}{l}\text { kulit men- } \\
\text { tah yang } \\
\text { memenuhi } \\
\text { kualitas }\end{array}$ & reject & \\
\hline Padang Panjang & 24.000 & 48 & 22.213 & 1.787 & 7,45 \\
\hline Bukittinggi & 11.000 & 22 & 10.468 & 532 & 4,84 \\
\hline Padang & 5.000 & 10 & 4.604 & 396 & 7,92 \\
\hline Solok & 3.500 & 7 & 3.253 & 247 & 7,06 \\
\hline Pariaman & 3.000 & 6 & 2.757 & 243 & 8,10 \\
\hline Pekanbaru & 1.500 & 3 & 1.426 & 74 & 4,93 \\
\hline Medan & 1.000 & 2 & 943 & 57 & 5,70 \\
\hline Jambi & 1.000 & 2 & 944 & 56 & 5,60 \\
\hline Total & 50.000 & & 46.608 & 3.392 & 6,78 \\
\hline
\end{tabular}

Tabel 2. Data berat (kg) dan luas $\left(\mathrm{ft}^{2}\right)$ kulit kambing awet garam menurut kelompok ukuran panjang garis punggung.

\begin{tabular}{ccccc}
\hline $\begin{array}{c}\text { Kelompok ukuran } \\
\text { panjang }(\mathrm{cm})\end{array}$ & Kategori & $\begin{array}{c}\text { Jumlah kulit } \\
\text { yang diukur } \\
\text { (Lembar) }\end{array}$ & $\begin{array}{c}\text { Berat kulit rata- } \\
\text { rata/lembar }(\mathrm{kg})\end{array}$ & $\begin{array}{c}\text { Luas rata-rata kulit/lem- } \\
\text { bar }\left(\mathrm{ft}^{2}\right)\end{array}$ \\
\hline$>100$ & 1 & 15 & $30,5 \pm 4,93$ & $96,07 \pm 8,40$ \\
$91-100$ & 2 & 25 & $39,0 \pm 2,91$ & $122,85 \pm 9,15$ \\
$81-90$ & 3 & 46 & $65,7 \pm 3,08$ & $206,95 \pm 11,55$ \\
$70-80$ & 4 & 14 & $16,6 \pm 2,50$ & $52,29 \pm 4,99$ \\
Jumlah & & 100 & 151,8 & 478,17 \\
rata-rata & & & 1,51 & 4,78 \\
\hline
\end{tabular}

ini diperoleh berdasarkan nilai konversi rata-rata kulit kambing 3,15 $\mathrm{ft}^{2} / \mathrm{kg}$ (Buchori et al., 1999). UPTD Padang Panjang memiliki standar tertentu untuk mengelompokkan kualitas kulit. Penentuan kualitas kulit ditentukan oleh panelis dengan beberapa kriteria diantaranya panjang garis punggung, luas kulit, dan tingkat kerusakan pada kulit. Menurut Karimah (2015), ketentuan-ketentuan dalam penetapan kualitas kulit dibagi kedalam beberapa kelas, tergantung pada jenis kerusakan, banyak kerusakan, lokasi kerusakan, dan luas kulitnya (per square feet). Buchori et al. (1999) melaporkan bahwa luas kulit kambing awet garam tiap lembar adalah $4,68 \mathrm{ft}^{2}$. Setiap perusahaan juga memiliki standar tersendiri dalam pengelompokan kulit mentah sesuai dengan tujuan penggunaan kulit tersamak nantinya.

Panjang, luas kulit dan ketebalan pada kulit mentah dapat menjadi salah satu standar untuk mengelompokan kualitas kulit mentah sebelum dijadikan sebagai bahan baku penyamakan kulit pada industri. Menurut Suardana et al. (2008) menyatakan ukuran kulit kambing ditentukan berdasarkan panjang tengah-tengah dari ekor hingga leher dan lebar kulitnya. Data ketebalan dan lebar rata-rata kulit mentah disajikan pada Tabel 3. Cara pelaksanaan pengukuran kulit dapat dilihat pada Gambar 1. Parameter dimensi kulit dapat juga digunakan sebagai acuan untuk menentukan kualitas kulit mentah sebelum penyamakan. Ketebalan kulit kambing dari bahan baku penyamakan kulit di UPTD berkisar antara $0,8-2,3 \mathrm{~mm}$. Ketebalan 
Tabel 3. Data hasil pengukuran lebar dan tebal kulit kambing.

\begin{tabular}{lcccc}
\hline \multicolumn{1}{c}{ Parameter } & Kategori & Kelompok ukuran & $\begin{array}{c}\text { Jumlah kulit yang } \\
\text { diukur (Lembar) }\end{array}$ & Rata-rata \\
\hline Lebar $(\mathrm{cm})$ & 1 & $<55$ & 7 & $51,85 \pm 2,74$ \\
& 2 & $55-70$ & 77 & $64,31 \pm 5,13$ \\
& 3 & $>70$ & 16 & $88,87 \pm 3,90$ \\
$\begin{array}{l}\text { Ketebalan } \\
(\mathrm{mm})\end{array}$ & 1 & $<1$ & 4 & $0,85 \pm 0,05$ \\
& 2 & $1-1,5$ & 53 & $1,49 \pm 0,23$ \\
Jumlah & 3 & $>1,5$ & 43 & $1,57 \pm 0,18$ \\
\hline
\end{tabular}

kulit menjadi menentu juga pada kualitas kulit jadi. Dimana ada hubungan ketebalan kulit dengan kekuatan tarik kulit. Sebagai perbandingan hasil penelitian dikemukakan Mustakim et al. (2010) menyatakan bahwa ketebalan dari kulit kambing bervariasi tergantung dari jenis dan umur ternak dimana tebal kulit kambing jenis Peranakan Boor memiliki ketebalan kulit 0,79 $\mathrm{mm}$, sedangkan ketebalan kulit kambing Peranakan Etawa adalah 0,74 mm. Purnomo (1991) menyatakan ketebalan kulit berpengaruh terhadap kekuatan tarik kulit dimana semakin tebal kulit maka semakin besar pula kuat tariknya dalam keadaan perlakuan yang sama. Kasim et al. (2013) juga melaporkan dimensi kambing kambing Ettawa di Sumatera Barat memiliki panjang 101,8 cm, lebar 81,511 $\mathrm{cm}$, dan tebal 0,12 $\mathrm{mm}$.

Menurut panelis di UPTD Penyamakan Kulit Padang Panjang, kualitas kulit kambing ditentukan berdasarkan panjang garis punggung mulai dari ekor hingga leher dan lebar kulitnya. Kualitas 1 adalah kulit mentah dengan panjang $100 \mathrm{~cm}$ dan lebar $>70 \mathrm{~cm}$. Kulit dengan kualitas 2 memiliki panjang $80-90 \mathrm{~cm}$ dan lebar $55-70 \mathrm{~cm}$, kulit kualitas 3 memiliki panjang $<80 \mathrm{~cm}$ dengan lebar $<50 \mathrm{~cm}$, sedangkan kualitas reject adalah kulit mentah dengan cacat yang merata dan kulit mentah dengan potongan yang tidak sesuai. Berdasarkan kriteria dimensi kulit mentah, kualitas kulit mentah yang diolah di UPTD rata-rata adalah kualitas 2 dan kualitas 3. Menurut Kusuma et al. (2013) kulit mentah yang dihasilkan untuk dari proses pemotongan ternak memiliki kualitas yang berbeda-beda karena dipengaruhi oleh beberapa faktor seperti jenis ternak, pakan, dan kondisi lingkungan. Ketebalan kulit dipengaruhi oleh komposisi kimia penyusun kulit tersebut.
Menurut Purnomo (1991) menyatakan kulit yang mempunyai serabut-serabut lebih horizontal dan kurang rapat atau lunak akan menyebabkan tebal kulit akan lebih tipis dibanding kulit yang mempunyai serabut-serabut lebih tegak dan anyaman lebih rapat.

\section{Cacat pada Kulit}

Pengamatan post-mortem terhadap cacat pada kulit kambing meliputi bulu rontok, benjolan caplak, tukak, dan jumlah lubang pada kulit akibat irisan dapat dilihat pada grafik Gambar 2. Persentase kulit cacat merupakan jumlah kulit yang rusak dari jumlah sampel yang diamati. Pengamatan post-mortem terhadap cacat pada kulit dari Gambar 2 dapat dijabarkan bahwa bulu rontok $6 \%$, benjolan caplak $14 \%$, tukak $5 \%$. Hal ini menunjukkan bahwa cacat kulit kambing paling dominan disebabkan oleh benjolan akibat caplak dibandingkan dengan cacat kulit lainnya. Cacat pada kulit yang disebabkan oleh penyakit seperti bulu rontok, benjolan caplak, dan tukak juga mempengaruhi kualitas produk kulit meskipun dari hasil pengamatan menunjukkan jumlah sedikit. Menurut Rotinsulu et al. (2015), cacat pada kulit kambing merupakan kerusakan yang ditimbulkan selama pemeliharaan ternak yang telah terserang penyakit kulit dan tempat penampungan hewan yang kotor memungkinkan menjadi sarang bibit penyakit sehingga mudah terserang penyakit atau tertular. Menurut Ibrahim et al. (2005), cacat karena penyakit kulit menimbulkan benjolan keras atau lengkungan kecil pada permukaan kulit yang sulit dihilangkan.

Penyakit kulit pada hewan dapat menurunkan kualitas kulit mentah dan kulit tersamaknya. Penyakit kulit dapat berupa bulu rontok yang dise- 

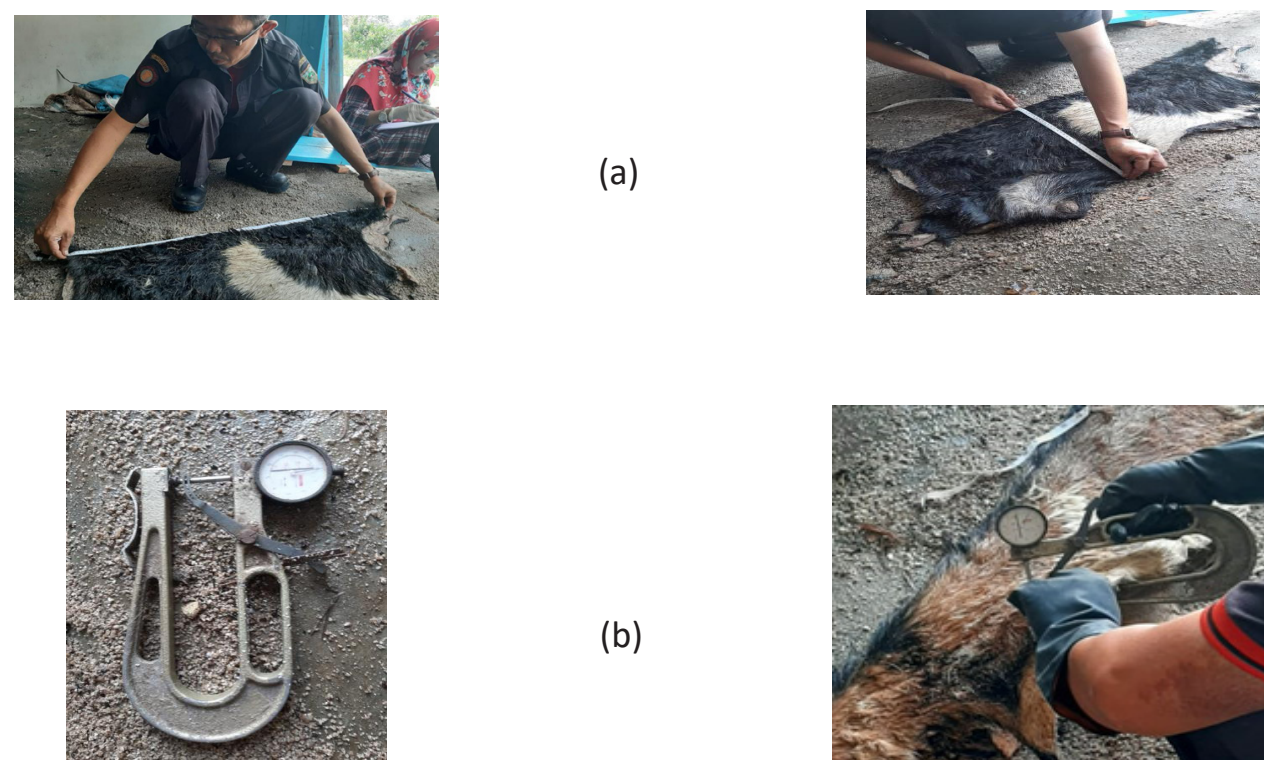

(a)

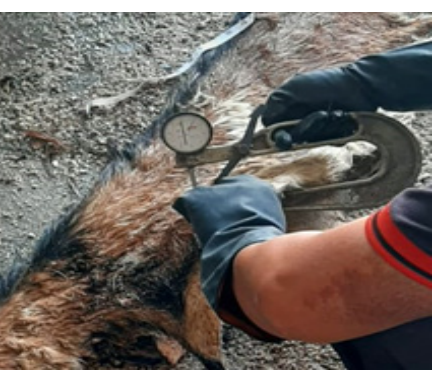

Gambar 1. Pengukuran panjang garis punggung dan lebar (a) serta ketebalan kulit kulit kambing (b).

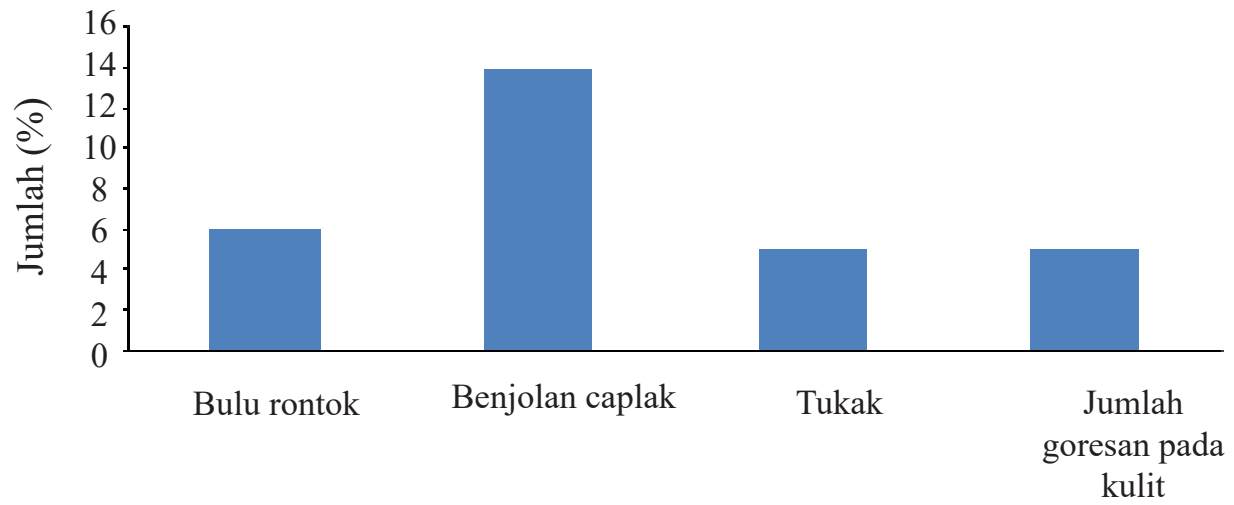

Gambar 2. Jumlah kulit cacat pada pengamatan post-mortem kulit kambing.

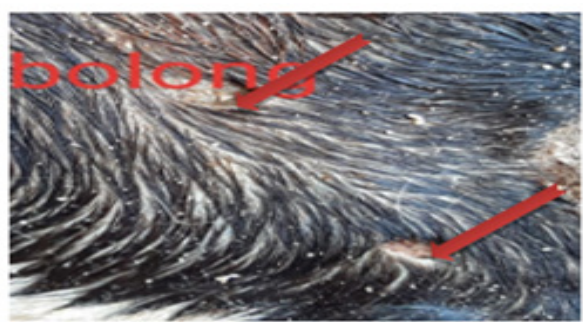

a

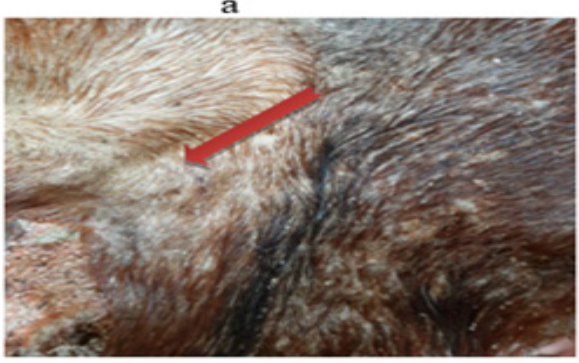

c.

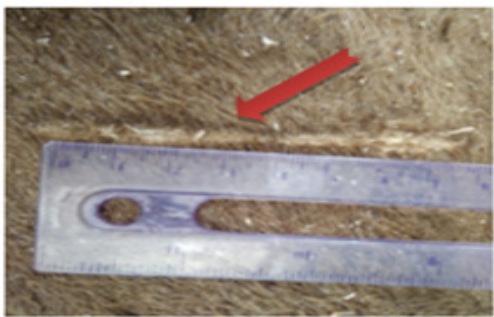

b

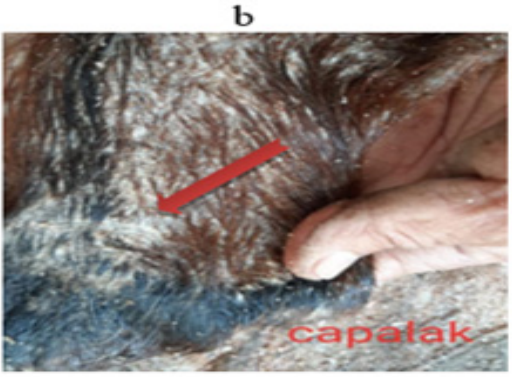

d

Gambar 3. Kondisi cacat pada kulit yang meliputi lubang pada kulit (a), luka akibat irisan pisau (b), bulu rontok (c), dan kerusakan akibat caplak (d). 
babkan oleh pelukaan kulit akibat penyakit caplak atau tukak akan tetapi juga dapat disebabkan oleh pengawetan kulit menggunakan garam. Menurut Triatmojo (2012), kontaminasi oleh parasit kulit dapat menyebabkan penyakit kulit kambing yang dapat mengakibatkan kerontokan bulu dan dapat menyerang muka, telinga, perut, punggung, dan pangkal ekor. Menurut Fahidin dan Muslich, (1999) penyakit yang dapat menurunkan kualitas kulit antaranya penyakit mulut dan kuku (PMK), rinderpest, cacar, dermatitis, scabies, ringworn dan tuberkolosis (Wijoseno et al., 2009). Kerusakan bagian epidermis kulit secara mekanis maupun mikrobiologis, akan berpengaruh terhadap penampilan permukaan kulit sampai setelah disamak (Said, 2012).

Cacat yang disebabkan oleh manusia yang juga dapat menurunkan kualitas kulit mentah adalah terdapatnya lobang akibat irisan pisau. Bentuk cacat pada kulit dapat dilihat pada Gambar 3. Irisan pada kulit akibat perlukaan yang terjadi akibat proses pelepasan kulit setelah proses pemotongan oleh petugas pemotongan hewan. Kualitas kulit dapat dijaga melalui kehati-hatian petugas di RPH dalam penanganan kulit saat pelepasan kulit hewan tersebut. Menurut Fahidin dan Muslich (1999), jenis pisau untuk pengulitan adalah pisau skinning agar adanya irisan pada proses pelepasan kulit hewan dapat dihindari. Menurut Triatmojo (2012), luka gesekan/goresan dapat menurunkan kualitas kulit. Goresan pada kulit akibat irisan pisau akan terlihat meskipun kulit telah selesai disamak. Kurang hati-hati dalam membuat irisan pada bagian dalam, terutama pada bagian subkutis sehingga bagian dermis (korium) akan ikut teriris akan mengakibatkan bagian daging dari subkutis tidak merata sehingga penampakannya sangat jelek. Hal ini yang mengakibatkan kualitas kulit menjadi menurun.

\section{KESIMPULAN}

Hasil pengamatan pakar di UPTD pengolahan kulit mentah yang memenuhi syarat untuk disamak adalah $93,22 \pm 4,15 \%$ dan rata-rata kulit reject adalah $6,45 \pm 1,33 \%$. Kualitas kulit mentah dari beberapa daerah yang menggunakan jasa UPTD untuk penyamakan kulit sebagian besar adalah kualitas 2 dan kualitas 3 . Berdasarkan pengamatan dimensi rata-rata kulit mentah memiliki luas kulit awet garam $4,78 \mathrm{ft}^{2}$, panjang $88,81 \mathrm{~cm}$, lebar $64,31 \mathrm{~cm}$, dan ketebalan 1,49 mm. Berdasarkan cacat pada kulit mentah nilai tertinggi disebabkan karena benjolan caplak sebanyak 14\%.

\section{UCAPAN TERIMAKASIH}

Terimakasih kepada Direktorat Jenderal Pendidikan Tinggi (DIKTI) dan Lembaga Pengelolaan Dana Pendidikan (LPDP) yang telah membiayai penelitian ini melalui Beasiswa BUDI-DN. UPTD Penggolahan Kulit Kota Padang Panjang Sumatera Barat.

\section{DAFTAR PUSTAKA}

Asosiasi Penyamak Kulit Indonesia. (2016). Kualitas pasokan kulit mentah ke industri rendah. https:// ekonomi.bisnis.com/read/20161130/257/607805/ kualitas-pasokan-kulit-mentah-ke-industri-rendah.

Atabany, A., Purwanto, B. P., Toharmat, T., \& Anggraeni, A. (2011). Hubungan masa kosong dengan produktivitas pada sapi perah Friesian Holstein di Baturraden, Indonesia. Journal Media Peternakan, 34(2), 77-82. https://doi.org/10.5398/ medpet.v34i2.3372

Buchori, A., Gukguk, R. R., \& Asrilah. (1999). Penelitian konversi hubungan timbal balik antara kulit kambing segar menjadi kulit garaman dan kulit pikel sebagai produk perdagangan. Majalah Barang Kulit, Karet Dan Plastik, 14(26), 1-8. https://doi.org/10.20543/mkkp.v14i26.292

Budisatria, I. G. S. (2009). Germ plasm of goats in Indonesia. Universitas Gadjah Mada, Yogyakarta.

Fahidin, \& Muslich. (1999). Ilmu dan teknologi kulit. Institut Pertanian Bogor, Bogor.

Hakim, T. R. (2018). Pengaruh jenis kelamin dan persentase Mimosa terhadap kualitas fisik kulit kambing (Skripsi). Universitas Mercu Buana Yogyakarta, Yogyakarta.

Ibrahim, L., Juliyarsi, I., \& Melya, S. (2005). Ilmu dan teknologi pengolahan kulit. Universitas Andalas, Padang.

Karimah, D. A. (2015). Sortasi dan grading kulit wet blue kulit kambing dan domba. Politeknik ATK Yogyakarta, Yogyakarta.

Kasim, A., Novia, D., Mutiar, S., \& Pinem, J. (2013). Karakterisasi kulit kambing pada persiapan penyamakan dengan gambir dan sifat kulit tersamak yang dihasilkan. Majalah Kulit, Karet, dan Plastik, 29(1), 1-12. https://doi.org/10.20543/mkkp. v29i1.213

Kusuma, A., Purnomoadi, A., \& Al-Baari, A. N. (2013). Perbandingan persentase kulit antara kambing Kejobong, kambing Peranakan Ettawah dan kambing Kacang jantan umur satu tahun. Animal Agriculture Journal, 2(1), 114-119.

Mustakim, Widati, A. S., \& Kurniawan, A. P. (2010). Perbedaan kualitas kulit kambing Peranakan Etawa (PE) dan Peranakan Boor (PB) yang disamak 
krom. Ternak Tropika, 11(1), 1-13.

Purnomo, E. (1991). Penyamakan kulit reptil. Akademi Teknologi Kulit, Yogyakarta.

Rotinsulu, M. D., Inal, H., Kalele, J. A. D., \& Tangkere, E. (2015). Pengamatan post-mortem kualitas kulit kambing di Kota Manado. Jurnal LPPM Bidang Sains dan Teknologi, 2(1), 89-94.

Said, M. I. (2012). Ilmu dan teknologi pengolahan kulit. Universitas Hasanuddin, Makasar.

Suardana, I., Sudiyadnyana, M., \& Rubyyanto. (2008). Kriya kulit jilid I. Direktorat Pembinaan Sekolah Menengah Kejuruan, Jakarta.

Sugiyono. (2011). Metode penelitian kuantitatif. Alfabeta, Bandung.

Sutyasmi, S. (2015). Sifat fisik, kimia, dan morfologik kulit jaket kambing tersamak menggunakan krom hasil recovery air limbah penyamakan. Majalah Kulit, Karet, dan Plastik, 31(2), 107-114. https:// doi.org/10.20543/mkkp.v31i2.176

Triatmojo, S. (2012). Teknologi pengolahan kulit sapi. PT Citra Aji Parama, Yogyakarta.

Wijoseno, R., Astiti, L. G. S., Panjaitan, T., Muzani, A., \& Agustini, N. (2009). Beternak kambing intensif (Brosur). Balai Pengkajian Teknologi Pertanian Nusa Tenggara Barat, Indonesia. Diakses: 17 Juni 2020.

Yudi. (2009). Pemeriksaan ante-post mortem. https:// drhyudi.blogspot.com/2009/07/pemeriksaanantepostmortem 